JIKAP PGSD: Jurnal Ilmiah Ilmu Kependidikan

Vol,2. No,2. Tahun 2018

e-ISSN: 2597-4440 dan p-ISSN: 2597-4424

(c) (1) This work is licensed under a Creative Commons Attribution

4.0 International License

\title{
Upaya Meningkatkan Kemampuan Membandingkan Pecahan Sederhana Dengan Menggunakan Kartu Pecahan Di Kelas III SD Negeri Majalaya VII
}

\author{
Sugi Alibowo \\ Prodi PGSD Universitas MH. Thamrin Jakarta \\ Email: sugi.alibowo@yahoo.com
}

\begin{abstract}
Abstrak: Penelitian ini bertujuan untuk meningkatkan hasil belajar matematika siswa kelas III SD Negeri Majalaya VII pada materi pecahan sederhana dengan menggunakan media kartu pecahan. Penggunaan media ini dilakukan melalui sebuah permainan. Jenis penelitian ini adalah penelitian tindakan kelas. Penelitian ini menggunakan model Kemmis dan Taggart. Subyek dalam penelitian ini adalah siswa kelas III SD Negeri Majalaya VII yang berjumlah 24 siswa. Teknik yang digunakan untuk pengumpulan data adalah teknik observasi dan tes tertulis. Instrumen penelitian menggunakan lembar observasi siswa dan tes tertulis. Teknik analisis data yang digunakan adalah deskriptif kuantitatif dan deskriptif kualitatif. Berdasarkan hasil yang diperoleh dapat disimpulkan bahwa: ketuntasan hasil belajar matematika dengan menggunakan media kartu pecahan siswa kelas III SD Negeri Majalaya VII mengalami peningkatan. Peningkatan pada siklus I sebesar 62,50\% sedangkan pada siklus II sebesar 79,17\%.
\end{abstract}

Kata kunci: hasil belajar matematika, media kartu pecahan

\begin{abstract}
This study aims to improve the mathematics learning outcomes of third grade students of Majalaya VII Elementary School in simple fraction materials using fractional card media. The use of this media is done through a game. This type of research is classroom action research. This study uses the Kemmis and Taggart model. The subjects in this study were third grade students of Majalaya VII State Elementary School, totaling 24 students. The techniques used for data collection are observation and written test techniques. The research instrument uses student observation sheets and written tests. Data analysis techniques used are descriptive quantitative and qualitative descriptive. Based on the results obtained it can be concluded that: the completeness of mathematics learning outcomes using fractional card media in third grade students of Majalaya VII State Elementary School has increased. The increase in the first cycle was $62.50 \%$ while in the second cycle was $79.17 \%$.
\end{abstract}

Keywords: mathematics learning outcomes, fractional card media

\section{PENDAHULUAN}

Objek dasar yang dipelajari dalam matematika merupakan hal-hal yang bersifat abstrak. Dikatakan abstrak karena objek tersebut hanya ada dalam pikiran, sehingga disebut dengan objek mental atau objek pikiran. Sifatnya yang abstrak dapat menimbulkan permasalahan belajar bagi siswa sekolah dasar dalam mempelajari matematika, seperti pada materi membandingkan pecahan sederhana yang diajarkan di kelas III. 
Permasalahan belajar yang timbul karena siswa sekolah dasar yang berada pada rentang usia 6-7 tahun sampai dengan 12-13 tahun sedang berada pada tahapan berpikir secara konkret. Pada tahap ini, siswa sekolah dasar sudah mampu berpikir rasional, namun masih terbatas pada situasi nyata.

Kesenjangan karakterisitik siswa sekolah dasar dengan sifat matematika inilah yang menimbulkan permasalahan kesulitan belajar untuk menguasai konsep matematika. Oleh sebab itu, untuk membantu menguasai konsep matematika khususnya materi membandingkan pecahan sederhana dapat dibantu dengan menggunakan media pembelajaran yang konkret, yaitu dengan menggunakan kartu pecahan. Kartu pecahan merupakan media pembelajaran yang efektif, karena memenuhi kriteria sebagai media pembelajaran yang baik, yaitu sederhana, mudah digunakan, mudah disimpan, memperlancar pembelajaran, tahan lama, sesuai dengan topik yang diajarkan, tidak menimbulkan salah tafsir dan mengarah pada satu pengertian.

Penggunaan kartu pecahan dalam pembelajaran matematika berguna sebagai pemusat perhatian siswa dan membantu siswa memahami materi membandingkan pecahan sederhana. Konsep pecahan yang abstrak dapat menjadi lebih konkret yang sesuai dengan tahapan berpikir siswa sekolah dasar.

Salah satu karakteristik anak usia sekolah dasar adalah senang bermain dan lebih suka bergembira riang. Karakteristik ini menuntut guru mengemas pembelajaran yang mengandung unsur permainan. Melalui permainan maka pembelajaran di dalam kelas dapat menjadi lebih aktif. Metode bermain dapat membuat siswa berinteraksi tidak hanya dengan guru dan siswa lainnya, tetapi juga berinteraksi dengan media pembelajarannya. Pemilihan teknik dan penggunaan media pembelajaran yang efektif harus selalu diterapkan oleh guru, sehingga siswa dapat mengkonstruksikan pemahamannya sendiri.

Posisi guru berperan sebagai fasilitator yang harus mampu membangkitkan ketertarikan siswa terhadap suatu materi pelajaran. Guru membimbing siswa mempertanyakan faktafakta, konsep-konsep, prinsip-prinsip, prosesproses maupun prosedur-prosedur yang relevan dengan materi pelajaran. Melalui aktivitas ini, siswa mengambil tanggung jawab untuk memantau kemajuan belajar mereka sendiri dan tugas belajar menjadi bersifat terbuka serta menantang untuk dikuasai.
Berdasarkan pada pengamatan di kelas III SDN Majalaya VII, kemampuan siswa pada materi membandingkan pecahan sederhana masih kurang memadai dan metode bermain kartu pecahan sebagai alat bantu belajar belum pernah diterapkan. Hal ini terlihat dengan masih banyaknya anak yang belum mampu membandingkan pecahan, mana yang lebih besar nilainya dan mana yang lebih kecil nilainya. Melalui penelusuran dokumentasi, masih banyak nilai siswa berada di bawah KKM yang ditetapkan yaitu 70. Dari 42 siswa, hanya $42,85 \%$ atau 18 siswa yang mampu mengerjakan soal tes yang diberikan. Sisanya, sebesar $57,15 \%$ atau sebanyak 24 siswa belum mampu mencapai nilai KKM. Menyadari kekurangan tersebut, peneliti terdorong untuk meningkatkan kemampuan siswa dalam pelajaran matematika materi membandingkan pecahan sederhana yang akan berpengaruh terhadap hasil belajar siswa itu sendiri.

Berdasarkan pada uraian di atas, maka peneliti melakukan penelitian tindakan kelas dengan tujuan untuk meningkatkan kemampuan membandingkan pecahan sederhana pada siswa kelas III SDN Majalaya VII. Peneliti terjun langsung dalam kegiatan belajar mengajar dengan memberikan stimulus pembelajaran melalui kartu pecahan. Oleh karena itu, penulis melakukan penelitian tindakan kelas dengan judul "Upaya Meningkatkan Kemampuan Membandingkan Pecahan Sederhana dengan Menggunakan Kartu Pecahan di Kelas III SD Negeri Majalaya VII".

Hasil penelitian Denik Nugraheni, Usada, dan Siti Kamsiyati di program studi PGSD FKIP Universitas Sebelas Maret Surakarta dengan judul "Penggunaan Media Kartu Pecahan Untuk Meningkatkan Hasil Belajar Matematika Konsep Pecahan" yang dilaksanakan di kelas III SDN I Mento Wonogiri tahun 2011, menunjukan bahwa rata-rata hasil tes siswa sesudah perlakuan terjadi peningkatan ketuntasan belajar. Pada tes awal yang baru mencapai $26,92 \%$, dapat meningkat pada siklus I menjadi $73,08 \%$, dan pada siklus II menjadi $96,15 \%$.

Penelitian Komariyah dan Budiyono Sadiman dari PGSD FIP Universitas Negeri Surabaya pada bulan Mei sampai dengan Juni tahun 2012 di kelas V SD Al-Amin Surabaya dengan judul "Penggunaan Media Kartu Bilangan Untuk Meningkatkan Hasil Belajar Penjumlahan Dan Pengurangan Bilangan Pecahan Pada Mata Pelajaran Matematika Siswa 
Kelas V Sd Al-Amin Surabaya" menunjukan bahwa penggunaan media kartu dapat meningkatkan hasil pembelajaran pemahaman konsep penjumlahan dan pengurangan bilangan pecahan. Terdapat peningkatan persentase hasil belajar dari siklus I yang hanya mencapai $68 \%$ menjadi $85 \%$.

Hasil penelitian Alamul Iman pada program studi PGSD FKIP Universitas Tanjungpura Pontianak di Kelas V Sekolah Dasar Negeri 05 Manis Mata Kabupaten Ketapang tahun 2013 menunjukan peningkatan hasil belajar siswa pada materi pecahan dengan menggunakan kartu pecahan. Pada siklus I, perolehan nilai rata-rata hasil belajar siswa adalah 63,6 dengan jumlah siswa tuntas 8 orang dan tidak tuntas 6 orang. Kemudian terlampaui menjadi rata-rata 85,7 pada siklus II dan seluruh siswa mencapai ketuntasan.

\section{Kemampuan Membandingkan Pecahan Sederhana}

Sasaran utama dari tujuan belajar matematika adalah sesuai dengan hakikat matematika itu sendiri, yaitu pemahaman terhadap konsep-konsep matematika yang relatif abstrak (Karso, 2011). Peranan dari teori belajar merupakan strategi terhadap pemahaman matematika. Teori-teori belajar tentang pengalaman lingkungan dan manipulasi benda konkret hanyalah sekedar jembatan dalam memahami konsep-konsep matematika, sehingga matematika dapat dipahami secara wajar sesuai dengan kemampuan anak.

Bilangan yang menyatakan bagian dari sesuatu yang utuh atau satu kelompok disebut pecahan. Pembilang menunjukan bilangan utuh yang dibagi, sedangkan penyebut menunjukan banyaknya pembagian pecahan tersebut. Muhsetyo mengungkapkan bahwa pecahan pada prinsipnya menyatakan beberapa bagian dari sejumlah bagian yang sama (Muhestyo, 2007). pada prinsipnya pecahan digunakan untuk menyatakan beberapa bagian dari sejumlah bagian yang sama. Dengan perkataan lain pecahan adalah bagian-bagian yang sama dari keseluruhan.

Sebagai contoh, seorang ibu yang baru pulang dari pasar membawa sepotong roti dan akan memberikan roti tersebut pada 2 anaknya. Agar kedua anak tersebut mendapat bagian yang sama, maka sepotong roti tersebut harus dibagi menjadi 2 bagian. Di dalam pembagian tersebut, maka setiap anak memperoleh bagian $\frac{1}{2}$ (setengah/ seperdua/ satu per dua) potong. Angka 1 disebut sebagai pembilang dan angka 2 disebut sebagai penyebut. $\frac{1}{2}=\frac{\text { pembilang }}{\text { penyebut }}$ Pembilang merupakan angka bilangan yang menunjukkan angka yang dibagi. Sedang penyebut merupakan angka pecahan yang menunjukkan pembaginya. Jadi, makna $\frac{a}{b}$ adalah a dibagi $b$.

Pada fase ini kemampuan yang tampak adalah kemampuan dalam proses berpikir untuk mengoperasikan kaidah-kaidah logika, meski masih terikat dengan objek yang bersifat konkret. Dalam pembelajaran matematika yang abstrak, siswa membutuhkan alat bantu berupa media dan alat peraga yang dapat memperjelas apa yang disampaikan oleh guru. Melalui media atau alat peraga tersebut siswa dapat lebih mudah mengerti dan memahami sebuah materi pelajaran.

Dalam merencanakan proses pembelajaran, guru harus menyesuaikan dengan karakteristik yang dimiliki siswa. Oleh sebab itu, maka seorang guru memerlukan strategi yang tepat dalam penyusunan proses pembelajaran. Menurut March (Izzaty, 2008), strategi guru dalam pembelajaran pada masa kanak-kanak akhir adalah sebagai berikut dibawah ini:

1. Menggunakan bahan-bahan yang konkret.

2. Menggunakan alat visual.

3. Gunakan contoh-contoh yang sudah akrab dengan anak dari hal yang bersifat sederhana ke yang bersifat kompleks.

4. Menjamin penyajian yang singkat dan terorganisasi dengan baik.

5. Beri latihan nyata dalam menganalisis masalah atau kegiatan

Di sekolah dasar, kelas terdiri dari 2 yaitu kelas rendah dan kelas tinggi. Kelas I, II, dan III termasuk dalam kelas rendah. Sedangkan kelas IV, V, dan VI termasuk pada kelas tinggi. Kelas rendah termasuk ke dalam masa kanakkanak akhir. Karena siswa masih berada pada fase operasional konkret, maka dibutuhkan alat bantu konkret dalam memahami sebuah konsep, terutama pada pembelajaran matematika.

Pada materi pecahan sederhana, alat bantu berupa media pembelajaran dapat memperjelas dan membantu siswa memahami materi pelajaran. Salah satu media yang tepat untuk membantu materi pecahan sederhana adalah kartu pecahan. Dengan menggunakan kartu pecahan ini, maka siswa dapat mudah membandingkan pecahan dengan cepat. Penggunaan media kartu ini dapat memberikan 
kesenangan pada siswa di dalam belajar karena dikemas dalam bentuk permainan. Belajar sambil bermain sangat sesuai dengan karakteristik siswa kelas III SD.

\section{Media Kartu Pecahan}

Kartu pecahan merupakan suatu media pembelajaran yang dapat digunakan untuk menarik minat siswa dalam pembelajaran matematika. Menarik minat siswa karena pembelajaran dilakukan dengan cara bermain.

Media kartu pecahan merupakan media pembelajaran yang digunakan untuk membantu guru dalam menjelaskan konsep pecahan sederhana, berkaitan dengan penelitian tindakan kelas ini kompetensi dasarnya adalah membandingkan pecahan. Kartu pecahan berbentuk persegi panjang dengan ukuran $5 \mathrm{~cm} \mathrm{x}$ $10 \mathrm{~cm}$. bahan yang digunakan untuk membuat kartu pecahan ini adalah kertas karton. Pada bagian luar akan dibalut dengan kertas asturo dan plastik untuk menjaga kualitas kartu.

Masing-masing kartu pecahan terbagi menjadi 2 bagian. Bagian atas terdapat angka pecahan, sedangkan bagian bawah kartu terdapat gambar yang menjelaskan angka pecahan tersebut. Di bawah ini merupakan desain media kartu pecahan yang digunakan di dalam penelitian ini.

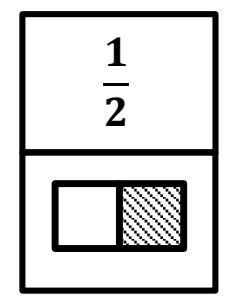

\section{Gambar 1. Desain Kartu Pecahan}

Secara fisik kartu pecahan ini mudah dibuat dan tidak memerlukan biaya yang besar. Bentuk dan warnanya menarik, sederhana, mudah dikelola dan tahan lama. Pembelajaran matematika akan menjadi lebih menyenangkan serta membantu siswa belajar aktif dan mandiri.

Berdasarkan pada aturan dalam menggunakan kartu pecahan, penggunaan media ini memiliki beberapa kelebihan. Siswa merasa gembira di dalam pembelajaran materi pecahan sederhana dengan kompetensi perbandingan karena pembelajaran dikemas dalam bentuk permainan. Pemahaman siswa akan meningkat mengenai konsep perbandingan pecahan sederhana. Selain itu, penggunaannya dapat meningkatkan hasil belajar siswa.
Kekurangan dari penggunaan media kartu pecahan adalah dalam pelaksanannya membutuhkan waktu yang sedikit lebih lama dibandingkan dengan metode ceramah. Untuk mengantsipasi kekurangan tersebut, maka ada beberapa tindakan yang harus dilakukan dalam pelaksanannya. Guru harus dapat mengatur waktu sebaik mungkin dalam pelaksanaan permainan. Pendampingan oleh guru terus dilakukan selama permainan berlangsung agar bila ada yang mengalami kesulitan dalam permainan, maka memperoleh bimbingan dari guru

\section{METODE}

Metode penelitian yang digunakan adalah penelitian tindakan kelas dengan model Kemmis dan Taggart yang meliputi tahap perencanaan, tindakan, observasi, serta kegiatan refleksi. Teknik pengumpulan data menggunakan triangulasi data dan penilaian pada anak.

\section{HASIL DAN PEMBAHASAN}

Tujuan penelitian ini bertujuan untuk meningkatkan kemampuan membandingkan pecahan sederhana pada siswa kelas III SD Negeri Majalaya VII. Penelitian ini dilaksanakan di SD Negeri Majalaya VII Kabupaten Bandung pada tahun ajaran 2017/ 2018 pada semester genap. Berikut merupakan jadwal penelitian tindakan kelas.

Berdasarkan hasil penelitian yang dilaksanakan di kelas III SD Negeri Majalaya VII, menunjukan bahwa pembelajaran matematika materi pecahan sederhana kompetensi dasar membandingkan pecahan sederhana dengan menggunakan media kartu pecahan mampu meningkatkan hasil belajar siswa. Siswa lebih mudah memahami materi membandingkan pecahan sederhana melalui permainan menggunakan media kartu pecahan. Pembelajaran lebih menarik, menyenangkan, lebih bermakna dan semua siswa aktif mengikuti proses pembelajaran. Selain itu, melalui pembelajaran ini, siswa dilatih untuk memiliki keterampilan berpikir maupun keterampilan sosial seperti bekerja sama, dan mampu memberikan apresiasi kepada siswa yang lain.

Ketuntasan belajar siswa terjadi peningkatan dari semula sebesar $45,83 \%$ pada pra siklus, $62,50 \%$ pada siklus I, dan $79,17 \%$ pada siklus II. Kenaikan ketuntasan belajar siswa tersebut membuktikan bahwa penggunaan media kartu pecahan sesuai bila digunakan untuk 
pembelajaran matematika materi membandingkan pecahan sederhana.

Siswa mengalami kesulitan dalam melakukan permainan kartu pecahan pada siklus I, sedangkan pada siklus II sebagian besar siswa tidak mengalami kesulitan dalam melakukan permainan kartu pecahan. Penggunaan kartu pecahan dalam pembelajaran menarik perhatian siswa dan menjadikan siswa semakin tertarik untuk belajar.

Ketidakefektifan dalam penelitian ini terjadi saat siswa melakukan post test pada siklus I. Masih kurang pahamnya siswa menjadikan waktu pengerjaan post test lebih lama dari yang direncanakan. Untuk meminimalisir hal tersebut, maka dilakukan perbaikan pada siklus II dengan memberikan contoh bagaimana mengerjakan soal-soal post test.

Rata-rata nilai hasil belajar siswa pra siklus sebesar 62,50 meningkat menjadi 68,33 pada siklus I, meningkat lagi pada siklus II menjadi 75,83. Hal ini menggambarkan peningkatan jumlah siswa yang tuntas belajar.

Jumlah siswa yang tuntas pada pra siklus sebanyak 11 siswa, siklus I sebanyak 15 siswa, dan pada siklus II sebanyak 19 siswa. Respon siswa sangat baik terhadap pembelajaran matematika menggunakan media kartu pecahan. Data yang telah dideskripsikan di atas, merupakan hasil dari implikasi tindakan yang telah dilaksanakan, dan karena $70 \%$ dari jumlah siswa mencapai nilai KKM, maka penelitian ini diakhiri pada siklus II.

\section{SIMPULAN DAN SARAN}

Berdasarkan hasil penelitian dan pembahasan yang telah diuraikan sebelumnya dapat disimpulkan bahwa: 1) Nilai rata-rata hasil belajar siswa pada mata pelajaran matematika materi membandingkan pecahan sederhana meningkat menjadi 75,83 pada siklus II dari 62,50 pada pra siklus dan 68,33 pada siklus I; dan 2) Jumlah siswa yang tuntas belajar juga meningkat pada siklus II menjadi $79,17 \%$ dari sebelumnya $45,83 \%$ (pra siklus) dan $62,50 \%$ (siklus I).

Penerapan pembelajaran matematika materi membandingkan pecahan sederhana dengan menggunakan kartu pecahan pada siswa kelas 3 SD Negeri Majalaya VII dapat meningkatkan hasil belajar siswa. Selain itu, berdasarkan pada observasi, antusiasme dan tingkat keaktifan siswa dalam mengikuti kegiatan belajar juga turut meningkat).

\section{DAFTAR RUJUKAN}

Agip, Zainal dkk. Penelitian Tindakan Kelas untuk Guru SD, SLB, dan TK. Yrama Widya Bandung, 2009.

Arikunto, S. Dasar-dasar Evaluasi Pendidikan. Jakarta: Bumi Aksara, 2008.

Izzaty, R. E. Perkembangan Peserta Didik. Yogyakarta: UNY Press, 2008.

Karso, \& dkk. Pendidikan Matematika I. Jakarta: Universitas Terbuka, 2011.

Muhsetyo, G., \& dkk. Pembelajaran Matematika SD. Jakarta: Universitas Terbuka, 2007.

Slameto. Proses Belajar Mengajar. Jakarta: Remaja Rosdakarya, 2008. 